Jurnal Agro Vol. 2, No. 2, Desember 2015

\title{
ISOLASI MIKROORGANISME PENAMBAT NITROGEN SIMBIOTIK DARI TANAMAN PELINDUNG SEMENTARA PADA PERKEBUNAN TEH DATARAN TINGGI
}

\author{
ISOLATION OF SYMBIOTIC NITROGEN FIXING MICROORGANISM \\ FROM TEMPORARY SHADE TREE ON HIGHLAND TEA PLANTATION
}

\author{
Eko Pranoto \\ Pusat Penelitian Teh dan Kina (PPTK) Gambung \\ Korespondensi : ekogambung@gmail.com \\ Diterima 30 November 2015 /Disetujui 23 Desember 2015
}

\begin{abstract}
ABSTRAK
Pemupukan merupakan salah satu input faktor pada perkebunan teh yang terus mengalami peningkatan harga. Penurunan biaya pokok dapat diupayakan melalui peningkatan efisiensi dan efektivitas pemupukan. Tanaman teh dapat tumbuh dan berproduksi dengan baik pada ketinggian minimal 700 meter di atas permukaan laut. Seiring pertumbuhannya, tanaman teh juga membutuhkan tanaman pelindung untuk membantu dalam pengurangan evaporasi, mengurangi froze, sebagai wind breaker, dan juga sebagai sumber bahan organik. Pada masa Tanaman Belum Menghasilkan (TBM), tanaman pelindung yang dipakai adalah tanaman pelindung sementara yang merupakan tanaman Leguminosa dan bersimbiosis dengan Rhizobium sp. yang dapat memfiksasi nitrogen dari udara dan menghasilkan fitohormon IAA sebagai biokatalisator yang dapat mempercepat pertumbuhan tanaman. Setiap tanaman Leguminosa bersimbiosis dengan Rhizobium sp. yang spesifik dan berbeda-beda pada satu jenis tanaman dan ketinggian tempatnya. Oleh karena itu, perlu dilakukan penggalian potensi alam lokal yang terdapat pada daerah tanaman teh dataran tinggi, khususnya Rhizobium sp. dari tanaman Leguminosa yang merupakan pohon pelindung tanaman teh. Tujuannya adalah agar diperoleh karakter spesies Rhizobium sp. dataran tinggi yang pada tahap penelitian selanjutnya dapat dimanfaatkan untuk meningkatkan kesuburan tanah, meningkatkan produktivitas tanaman, dan akhirnya dapat mengoptimalkan biaya pemupukan pada perkebunan teh. Dari penelitian diperoleh enam spesies Rhizobium sp. dari perkebunan teh dataran tinggi yang diberi kode YA, YB, YC, YD, YE, dan YF. Secara makroskopis terdapat perbedaan pertumbuhan Rhizobium sp. tersebut dengan pertumbuhan tercepat adalah Rhizobium sp. dari tanaman pelindung sementara Tephrosia sp. dan Seisbania sp. pada perkebunan teh.
\end{abstract}

Kata kunci: Perkebunan Teh, Pohon Pelindung Sementara, Rhizobium sp.

\begin{abstract}
Fertilization is one of input factors on tea plantation that is increasing on the price. The decreasing of the main cost can be done by increasing the efficiency and effectiveness of fertilizing. Tea plant can be grown with high productivity at least at $700 \mathrm{~m}$ above sea level. Along with the growth, tea plant need shade tree to eliminate evaporation and froze, and act as a wind breaker and organic material source. Leguminose plants used on young tea is a
\end{abstract}


symbiotic plant with Rhizobium sp. This microorganism can fix Nitrogen from the air, and produce fitohormone such IAA functioning as bio-catalist to accelerate the plant growth. Every Leguminose plant has specific symbiosis with Rhizobium sp. depending on plant species and elevation. Furthermore, there is a need of exploration of the indigenous Rhizobium sp. from Leguminose shade tree at highland tea plantation. The aim was to get species characteristic of Rhizobium sp. that can be used for the next research to increase soil fertility, plant productivity, and optimize the fertilizer cost on tea plantation. The result found six species of Rhizobium sp. with code YA, YB, YC, YD, YE, and YF. Macroscopically, there were differences on the characteristic among them. The highest rate of growth were found for Rhizobium sp. from Tephrosia sp. and Seisbania sp. temporary shade trees on tea plantation.

Key words : Rhizobium sp., Tea Plantation, Temporary Shade Tree

\section{PENDAHULUAN}

Tanaman teh sebagian besar ditanam pada tanah Andosol (52\%), Latosol (15\%), Podzolik (18\%), dan Regosol (9\%) (Darmawijaya, 1976; 1979). Masing-masing jenis tanah tersebut mempunyai tingkat keserasian yang berbeda untuk tanaman teh, untuk mengetahui pengaruh pupuk terhadap tanaman teh perlu dilakukan pengujian pada berbagai jenis tanah tersebut. Untuk pertumbuhannya tanaman teh memerlukan hara makro $\mathrm{N}, \mathrm{P}, \mathrm{K}$, dan $\mathrm{Mg}$ dalam jumlah banyak yang diberikan melalui tanah dan unsur hara mikro $\mathrm{Zn}$ dalam jumlah sedikit diberikan dalam bentuk larutan sehingga produktivitas tanaman tidak menurun atau bahkan meningkat.

Tanaman teh merupakan tanaman yang dipanen pucuknya secara teratur, sehingga setiap faktor penentu pertumbuhan vegetatifnya perlu diperhatikan, antara lain adalah pemupukan. Pemupukan merupakan salah satu faktor produksi yang berperan langsung di dalam peningkatan produktivitas tanaman. Pemupukan bertujuan untuk menjaga kesinambungan unsur hara yang dibutuhkan tanaman untuk pertumbuhannya. Di dalam tanah, seiring dengan proses pembentukannya sudah ter- dapat sejumlah unsur hara dengan jumlah dan jenis yang fluktuatif. Hal ini tergantung pada jenis tanah, asal pembentukan, dan bahan organik yang terdapat pada tanah tersebut. Tanaman teh yang merupakan tanaman tahunan akan menyerap unsur hara yang ada pada tanah secara terus menerus, sehingga ketersediaan unsur hara tersebut akan semakin terkuras dan kesuburan tanah akan semakin terdegradasi. Oleh karena itu perlu dilakukan penambahan hara melalui pemupukan.

Pemupukan membutuhkan biaya yang sangat besar. Agar sasaran pemupukan dapat tercapai, pemupukan harus dilakukan dengan empat tepat, yaitu: (1) tepat waktu, (2) jenis, (3) cara, dan (4) tepat dosis, sehingga pemupukan bisa lebih efektif dan efisien.

Dosis umum pemupukan tanaman teh tergantung pada kadar hara tanah seperti yang tercantum pada Tabel 1 . Sedangkan kriteria hara tanah tanaman teh akan dipaparkan pada Tabel 2.

Pemupukan pada tanaman teh merupakan kebutuhan bagi tanaman untuk mempertahankan tingkat produktivitasnya. Pupuk untuk tanaman teh saat ini dapat digunakan dari pupuk tunggal seperti Urea, SP 36, MOP, Kieserit yang diberikan secara berimbang atau pupuk yang sudah dicam- 
pur baik pupuk majemuk atau pupuk campuran. Penggunaan pupuk anorganik yang terus menerus ternyata mempengaruhi reaksi dan struktur tanah yang selanjutnya berpengaruh terhadap kesuburan fisik kimia dan biologi tanah. Sehingga selain pupuk anorganik perlu mengkombinasikan peng- gunaan pupuk anorganik dengan pupuk hayati dan pupuk organik, menambah bahan organik untuk memperbaiki kesehatan tanah dan memperbaiki kesuburan biologi tanah (Rachmiati, 2010).

Tabel 1. Dosis baku pupuk (kg/ha/tahun) untuk tanaman menghasilkan (TM) dengan produksi minimal $2.500 \mathrm{~kg}$ teh kering/ha/tahun

\begin{tabular}{|c|c|c|c|c|c|c|}
\hline & \multirow{2}{*}{$\mathbf{N}$} & \multicolumn{2}{|c|}{$\mathrm{P}_{2} \mathrm{O}_{5}$} & \multirow{2}{*}{$\mathrm{K}_{2} \mathrm{O}$} & \multirow{2}{*}{ MgO } & \multirow{2}{*}{$\mathrm{ZnSO}$} \\
\hline & & Andisol/Regosol & Latosol/Podzolik & & & \\
\hline Rendah & 350 & 120 & 40 & 180 & 75 & 15,0 \\
\hline Sedang & 300 & 90 & 25 & 120 & 50 & 7,5 \\
\hline Tinggi & 250 & 60 & 15 & 60 & 30 & 5,0 \\
\hline
\end{tabular}

Sumber: PPTK Gambung 2006

Tabel 2. Kelas hara tanah pada tanaman teh

\begin{tabular}{lccccc}
\hline \multirow{2}{*}{ Jenis Hara } & \multicolumn{5}{c}{ Kriteria } \\
\cline { 2 - 6 } & $\begin{array}{c}\text { Sangat } \\
\text { Rendah }\end{array}$ & Rendah & Sedang & Tinggi & $\begin{array}{c}\text { Sangat } \\
\text { Tinggi }\end{array}$ \\
\hline $\mathrm{pH} \mathrm{H}_{2} \mathrm{O}$ & $<4,0$ & $4,1-4,5$ & $4,6-5,5$ & $5,6-6,0$ & $>6,1$ \\
C-organik (\%) & $<1,0$ & $1,1-3,0$ & $3,1-5,0$ & $5,1-8,0$ & $>8,1$ \\
$\mathrm{~N} \mathrm{Total} \mathrm{( \% )}$ & $<0,10$ & $0,11-0,30$ & $0,31-0,50$ & $0,51-0,80$ & $>0,81$ \\
$\mathrm{P}$ Potensial (mg/100) & $<10$ & $11-30$ & $31-60$ & $61-100$ & $>101$ \\
$\mathrm{P} \mathrm{Tersedia} \mathrm{(ppm)}$ & $<4$ & $5-9$ & $10-22$ & $23-40$ & $>41$ \\
$\mathrm{~K}$ Tersedia (me/100) & $<0,30$ & $0,31-0,50$ & $0,51-1,00$ & $1,01-1,50$ & $>1,51$ \\
$\mathrm{Mg}($ me/100) & $<0,50$ & $0,51-1,00$ & $1,01-1,50$ & $1,51-2,00$ & $>2,01$ \\
$\mathrm{Ca}$ (me/100) & $<2,50$ & $2,51-5,00$ & $5,01-7,50$ & $7,51-10,00$ & $>10,01$ \\
$\mathrm{KTK}(\mathrm{T} \%)$ & $<10$ & $11-20$ & $21-40$ & $41-50$ & $>51$ \\
Kejenuhan Basa (S/T \%) & $<20$ & $21-30$ & $31-50$ & $51-60$ & $>61$ \\
\hline
\end{tabular}

Sumber: PPTK Gambung 2006

Dosis pupuk yang diaplikasikan dapat dikurangi seiring dengan meningkatnya bahan organik pada wilayah tersebut. Beberapa fungsi bahan organik adalah meningkatkan kesuburan tanah, menggemburkan tanah, dan juga sebagai media pembiakan beberapa mikroba tanah. Di dalam tanah terdapat beberapa jenis mikroba yang terdiri dari jamur, bakteri, dan Actinomycetes. Sebagian bersifat patogen dan sebagian lagi bermanfaat untuk meningkatkan penyerapan unsur hara oleh tanaman.
Rhizobium sp. adalah mikroba yang bersimbiosis dengan tanaman Leguminosa yang dapat memfiksasi nitrogen dari udara. Setiap tanaman Leguminosa bersimbiosis dengan mikroba Rhizobium sp. yang spesifik dan berbeda-beda pada satu jenis tanaman dan pada dataran yang berbeda pula. Tanaman yang bersimbiosis dengan Rhizobium sp. ini hanya membutuhkan pemupukan yang sedikit dan biomassa-nya dapat dijadikan sebagai sumber bahan organik. Bahkan mikroba Rhizobium sp. tersebut dapat menghasilkan fitohormon IAA yang ber- 
fungsi sebagai biokatalisator untuk mempercepat pertumbuhan tanaman.

Tanaman teh dapat tumbuh dan berproduksi dengan baik pada ketinggian minimal 700 meter di atas permukaan laut ( $\mathrm{m} \mathrm{dpl).}$ Berdasarkan ketinggiannya, tanaman teh terbagi atas tiga bagian, yaitu: (1) Tanaman teh dataran rendah (ketinggian <900 $\mathrm{m}$ dpl); (2) Tanaman teh dataran sedang (ketinggian 900-1.200 m dpl); dan (3) Tanaman teh dataran tinggi (ketinggian >1.200 $\mathrm{m} \mathrm{dpl}$ ).

Seiring pertumbuhannya, tanaman teh juga membutuhkan tanaman pelindung untuk membantu dalam pengurangan evaporasi, mengurangi froze, sebagai wind breaker, dan juga sebagai sumber bahan organik. Pada masa Tanaman Belum Menghasilkan (TBM), tanaman pelindung yang dipakai adalah tanaman pelindung sementara yang merupakan tanaman Leguminosa seperti Crotalaria sp., Tephrosia candida, Sesbania sp., sedangkan pada masa Tanaman Menghasilkan (TM) banyak dipakai tanaman nonLeguminosa seperti Gravelia robusta. Sedangkan tanaman sengon (Albizia palcata) mulai dijadikan tanaman intercropping di perkebunan-perkebunan teh daerah Jawa Timur. Di India Selatan, tanaman jenis Acacia maernsi juga dipakai sebagai tanaman untuk mencegah terjadinya froze.

Daerah PPTK Gambung termasuk ke dalam Zona Fisiografi Depresi Bandung yang merupakan salah satu Zona Fisiografi utama yang terhampar di wilayah Jawa Barat dengan formasi geologi QtI (Quarter tilu lava) yakni suatu formasi geologi yang terbentuk oleh lava dan pasir volkan intermedier. Ciri utama daerah ini yaitu terdapat sinklin (lembah) karena pernah mengalami proses patahan yang cukup kuat. Berdasarkan Peta Rupa Bumi (Peta Topografi) dan peta tanah Jawa Barat tingkat Semidetil bentuk wilayah daerah ini termasuk lereng volkan dan lumpur volkan dengan bentuk wilayah bergelombang dengan kemiringan lereng 8-15\% dan beda tinggi 10-50 m, berbukit kecil dengan kemiringan lereng 15$30 \%$ dan beda tinggi 10-50 m, serta berbukit dengan kemiringan lereng $>30 \%$ dan beda tinggi 50-300 m (Ayu, 2004).

Oleh karena itu, perlu dilakukan penggalian potensi alam lokal yang terdapat pada daerah tanaman teh dataran tinggi, khususnya mikroba Rhizobium sp. dari tanaman Leguminosa yang merupakan pohon pelindung tanaman teh. Tujuannya adalah agar diperoleh spesies mikroba Rhizobium sp. dataran tinggi yang dapat dimanfaatkan untuk meningkatkan kesuburan tanah, meningkatkan produktivitas tanaman, dan akhirnya dapat mengoptimalkan biaya pemupukan pada perkebunan teh.

\section{BAHAN DAN METODE}

\section{Tempat dan Waktu}

Penelitian ini dilaksanakan di kebun percobaan PPTK Gambung, Jawa Barat dengan ketinggian $1.379 \mathrm{~m}$ di atas permukaan laut. Adapun jenis tanahnya adalah Andisols. Tanah Andisol mempunyai sifat spesifik antara lain: kandungan bahan organik tanah tinggi (>3\%), tekstur ringan, konsistensi gembur, berat jenis rendah $(<0,9$ $\mathrm{g} / \mathrm{cm}^{2}$ ), retensi $\mathrm{P}$ tergolong tinggi (>85\%). Kebun percobaan PPTK Gambung memiliki $\mathrm{pH}$ 4,5-5,4 dan tipe hujan B (Schmidt and Ferguson, 1951) dengan curah hujan ratarata $2.900-3.500 \mathrm{~mm} /$ tahun. Isolat mikroorganisme diambil dari bintil akar tanaman Leguminosa yaitu Crotalaria sp., Tephrosia candida, dan Seisbania sp. sebagai tanaman pelindung pada tanaman teh belum menghasilkan (TBM). Isolat diambil pada 
koordinat $07.13778^{\circ}$ Lintang Selatan dan $107.50294^{\circ}$ Bujur Timur.

\section{Metode Percobaan}

Bintil akar yang diperoleh dari tanaman Leguminosa dibersihkan dengan alkohol dan air aquadest sampai hilang partikel-partikel tanahnya. Setelah itu bintil akar yang berwarna merah jambu dipecahkan dan diberikan $1 \mathrm{cc}$ air aquadest steril. Lalu diambil sebagian larutan bintil akar tersebut dengan menggunakan jarum ose dan diisolasikan dengan cara menggoreskannya ke dalam petridish yang telah berisi media YEM agar modifikasi yang pH-nya disesuaikan untuk tanaman teh. Masing-masing tanaman diulang 3 (tiga) kali.

Selanjutnya petridish ditutup rapat dan dimasukkan ke dalam inkubator untuk

melihat pertumbuhannya. Setelah 3-5 hari, Rhizobium sp. yang tumbuh pada petridish dimurnikan dengan mengambil sebagian mikroba yang berada pada garis goresan sebanyak 3-5 kali pemurnian. Kemudian masing-masing isolat Rhizobium sp. dikoleksi pada media agar miring.

\section{HASIL DAN PEMBAHASAN}

Dari isolasi dan purifikasi (pemurnian) yang dilakukan diperoleh enam spesies yang diberi kode YA, YB, YC, YD, YE, dan YF yang berarti spesies Rhizobium sp. dari tanaman pelindung sementara pada TBM (Young Tea) dengan kode A sampai F. Hasil isolasi dan purifikasi ditampilkan pada Gambar 14.

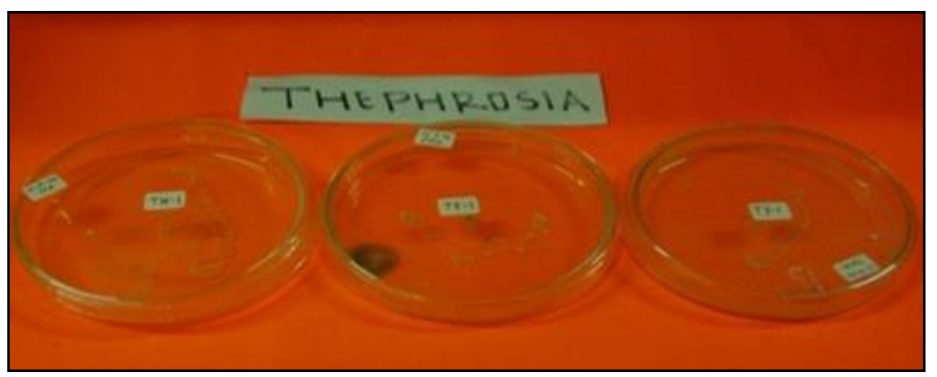

Gambar 1. Hasil isolasi Rhizobium sp. dari tanaman Thephrosia sp.

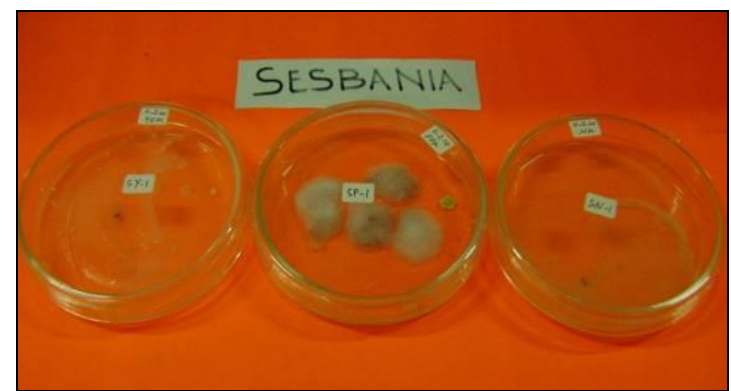

Gambar 2. Hasil isolasi Rhizobium sp. dari tanaman Sesbania sp. 


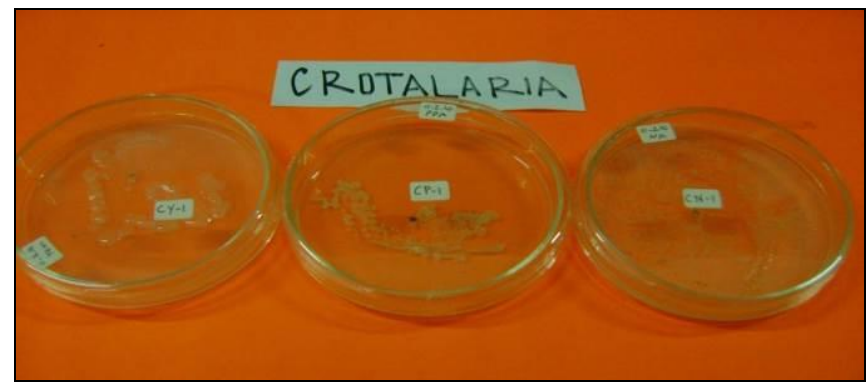

Gambar 3. Hasil isolasi Rhizobium sp. dari tanaman Crotalaria sp.

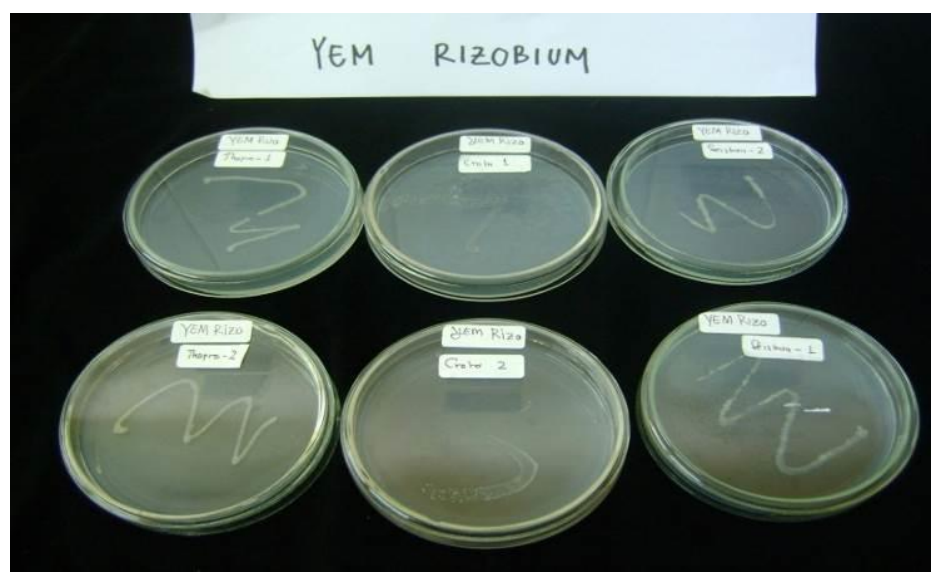

Gambar 4. Hasil purifikasi Rhizobium sp. dari tanaman Leguminosa perkebunan teh

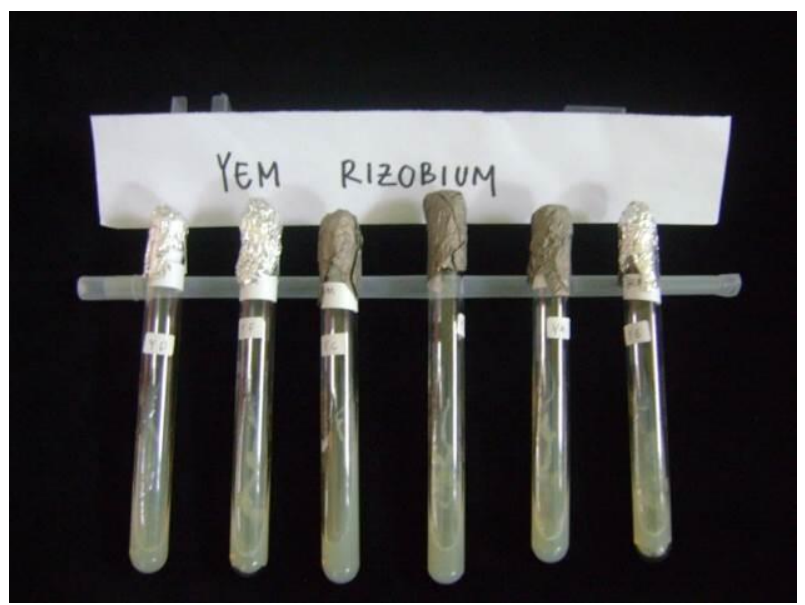

Gambar 5. Koleksi mikroba Rhizobium sp. yang diberi kode YA, YB, YC, YD, YE, dan YF

Rhizobium sp. merupakan bakteri penambat nitrogen yang bersimbiosis pada tanaman Leguminosa. Proses pemanfaatan Nitrogen tersebut dapat terjadi karena adanya senyawa kompleks yang dimiliki oleh makhluk hidup yang bersifat simbiotik maupun non simbiotik, yaitu enzim Nitrogenase. Kemampuan mikroba yang bersimbiosis dalam memfiksasi Nitrogen lebih besar bila dibandingkan dengan 
mikroba yang hidup bebas (non simbiotik). Tabel 3 berikut memaparkan kemampuan beberapa mikroba dalam memfiksasi Nitrogen. Berikut akan dijelaskan beberapa mikroba yang bersimbiosis dalam memfiksasi Nitrogen.

Tabel 3. Kemampuan Mikroba dalam Fiksasi Nitrogen

\begin{tabular}{lc}
\hline \multicolumn{1}{c}{$\begin{array}{c}\text { Tipe/Jenis } \\
\text { Mikroba }\end{array}$} & $\begin{array}{c}\text { Kemampuan } \\
\text { Fiksasi } \\
\text { (kg N/ha/thn) }\end{array}$ \\
\hline $\begin{array}{l}\text { Simbiosis } \\
\text { Rhizobium }\end{array}$ & $50-600$ \\
Actinomycetes & \\
Non Simbiotik & \\
Azospirillum & $12-313$ \\
Azotobacter paspal & $0,1-25$ \\
$\begin{array}{l}\text { Azotobacter } \\
\text { rhodospirillum } \\
\text { Klebsella }\end{array}$ & \\
Sumber : Dewi, 2007 & \\
\hline
\end{tabular}

Fiksasi $\mathrm{N}$ biologis melibatkan enzim mengubah $\mathrm{N}_{2}$ menjadi ammonia $\left(\mathrm{NH}_{3}\right)$, dimana bila dalam larutan kebanyakan terdapat dalam bentuk ammonium $\left(\mathrm{NH}_{4}\right)$. Komponen ini merepresentasikan molekul awal untuk biosintesis dari asam amino dan biomolekul lain yang mengandung Nitrogen. Berdasarkan informasi, hanya prokariot (anggota yang mendominasi Archaea dan Bacteria) yang mampu melaksanakan fiksasi biologis. Semua eukariot (termasuk tanaman tingkat tinggi) secara alami bergantung terhadap aktifitas fiksasi $\mathrm{N}$ biologis yang dilakukan oleh prokariot (diazotrop) untuk pemenuhan nitrogennya (Burgmann, 2003).

\section{SIMPULAN}

1. Diperoleh enam spesies Rhizobium sp. dari perkebunan teh dataran tinggi yang diberi kode YA, YB, YC, YD, YE, dan YF.

2. Secara makroskopis terdapat perbedaan pertumbuhan Rhizobium sp. tersebut, dengan pertumbuhan tercepat adalah Rhizobium sp. dari tanaman Tephrosia sp. dan Seisbania sp..

3. Setelah diperoleh Rhizobium sp. tersebut, selanjutnya akan dilakukan uji infektivitas dan efektivitasnya.

\section{UCAPAN TERIMAKASIH}

Penulis mengucapkan terimakasih kepada pihak Manajemen PPTK Gambung dan Ir. Yati Rachmiaiti, M.P. sebagai penanggung jawab kegiatan yang telah dibiayai oleh Balai Pengkajian Teknologi Pertanian (BPTP) Jawa Barat Kementerian Pertanian.

\section{DAFTAR PUSTAKA}

Anonymous, 2008. Fertilizer Placement. Internet. file:///G:/Benam\%20 Pupuk/ 0170-Fertilizer\%20 Placement.htm. [215-2008].

Ayu, H., 2004. Pembuatan Pupuk Organik dari Limbah Perkebunan dan Pabrik Teh di PPTK Gambung, Bandung. Laporan Praktek Lapang. Fakultas Pertanian IPB, Bogor.

Burgmann, Helmut. 2003. Activity and Diversity of Nitrogen-Fixing Microorganisms : Novel Tools to Characterize Populations in Soil. Dissertation. Swiss Federal Institut of Technology Zurich.

Darmawidjaya, I., 1982. Klasifikasi Tanah untuk Tanaman Teh. Evaluasi Penge- 
Iolaan UUK Simalungun tahun 2006, Bah Butong.

Dewi A, I. R. , 2007. Fiksasi N Biologis pada Ekosistem Tropis. Universitas Padjadjaran, Bandung

International Research Institute, 2006. Temperature and Presipitation. http://iri.columbia.edu/climate/ENSO/gl obalimpact/temp_precip/index.htm. [21-5-2008].

Litbang Deptan, 2008. Internet. http://pfi3p.litbang.deptan.go.id/mod.p $h p$ ?mod=userpage \&menu=1704\&page_i $d=20$. [11-8-2012].

Manivel, L. 1999. Physiology of Tea Productivity. Global and advance of Tea Science: 463-480.

Rachmiati, Y., 2010. Pemupukan pada Tanaman Teh. Disampaikan dalam Tea Quality Enhancement Workshop, Ethical Tea Partnership pada tanggal 14-15 Oktober 2010 di PPTK Gambung.

Riau Pos Online, 2 Agustus 2008. Harga TBS Berpengaruh pada Harga Pupuk. Internet http:// www.riaupos.com/v2/content/view/3023/59/. [21-5-2008].

Soil Survey Staff. 1998. Kunci Taksonomi Tanah. Edisi Kedua Bahasa Indonesia, 1999. Pusat Penelitian Tanah dan Agroklimat, Badan Penelitian dan Pengembangan Pertanian. Bogor

Statistik Teh Indonesia. 2001. Badan Pusat Statistik dan Asosiasi Teh Indonesia. Jakarta, September 2001.

Suara Surabaya, 16 April 2008. Harga Pupuk Bersubsidi Melonjak Tajam. Internet. http://www.suarasurabaya.net/v05/ekon omibisnis/?id=115f6f59f940912153d50b15 ac32b91a200851223. [16-4-2008].

Syari. S. 1986. Kesuburan dan Pemupukan Tanah Pertanian. Pustaka Buana. Jakarta.

Tim PPTK, 2006. Petunjuk Kultur Teknis Tanaman Teh. PPTK, Gambung.
Tim. 1991. Dasar-dasar Pertimbangan Program Replanting Teh. Hal. 23-48. Lokakarya Replanting.

Tim Rekomendasi Pemupukan PPTK Gambung, 2010. Rekomendasi Pemupukan Tanaman Teh PTPN VIII (Persero) Tahun 2010. PPTK Gambung.

Wibowo, Z. S. dan U.Verstrijen (1976). Nilai Baku Kadar Hara Daun Teh. Warta BPTK 2 (3/4) : 305-316 pp.

Wibowo, Z. S, 1990. Kekahatan Unsur Hara pada Tanaman Teh di Indonesia. Pusat Penelitian Teh dan Kina. Bandung. 9 hal. 